\title{
Методика оцінювання технічного стану силових елементів літаків-винищувачів за межами призначених показників
}

\author{
Максим Стрєла * 1 А \\ А Державний науково-дослідний інститут авіації, м. Київ, Україна
}

Received: August 1, 2021 | Revised: August 25, 2021 | Accepted: August 31, 2021

DOI: $10.33445 /$ sds.2021.11.4.11

\begin{abstract}
Анотація
Відповідно до Візії Повітряних Сил планується оновлення парку літальних апаратів на нові літаки, що знаходяться на озброєнні країн НАТО. Проте, в перехідний період переоснащення на нову техніку постає проблема підтримання справності старіючого парку літаків. Основна проблема в забезпеченні справності парку літаків Повітряних Сил - це значне вичерпання ресурсних показників через високу інтенсивність польотів. Мета статті полягає в оприлюдненні результатів досліджень щодо комплексу часткових методик оцінювання технічного стану силових елементів літаків-винищувачів, коли їх формальний ресурс вичерпаний. Ці часткові методики складають загальну методику оцінювання технічного стану силових елементів літаків-винищувачів за межами призначених показників. Використання загальної методики дозволить більш об'єктивно приймати рішення щодо продовження (збільшення) ресурсу силовим елементам літаківвинищувачів та визначати їх технічний стан із більшою точністю. Загальна методика використовує в розрахунках теорію імовірностей при обробці експлуатаційних даних, теорію механіки твердого тіла та метод кінцевих елементів при розрахунку напруженодеформованого стану, метод кластеризації та теорію розпізнавання образів при класифікації технічного стану. Незважаючи на використання такого різноманіття різних видів математичних розрахунків - методика $€$ інтуїтивно зрозумілою і достатньо практичною.
\end{abstract}

Ключові слова: літальний апарат, силовий елемент, ресурс, оцінювання технічного стану.

\section{Постановка проблеми}

Відповідно до Воєнної доктрини України [1] - формування національних оборонних можливостей буде здійснюватися шляхом підвищення бойового потенціалу, відновлення справності, продовження ресурсу, проведення модернізації військової техніки 3С України. У Візії Повітряних Сил зазначено [2], що старіючий парк літальних апаратів (ЛА) планується замінювати літаками, які знаходяться на озброєнні армій країн НАТО. Проте, період переоснащення на нові типи літальних апаратів передбачає поетапне заміщення старіючої техніки на нові зразки, що потребує в свою чергу підтримання справності та боєготовності застарілих ЛА до моменту їх списання.

Основна проблема в підтриманні справності старіючого парку ЛА - це значне вичерпання ресурсних показників агрегатів та комплектувальних виробів, ресурс яких відрізняється від ресурсу планера. Ця проблема склалась в результаті поступового вичерпування ремонтного фонду на авіаремонтних підприємствах та експлуатуючих частинах. Причина відсутності поповнення ремонтного фонду в тому, що виробник ЛА більше не постачає нові комплектувальні вироби та агрегати в Україну. Ця ситуація змушує виконувати

\footnotetext{
1 * Corresponding author: науковий співробітник науково-дослідної лабораторії, e-mail: maxim.strela1991@gmail.com, ORCID: 0000-0003-4055-1600
} 
пошук шляхів до визначення реального граничного стану силових елементів ЛА до моменту освоєння їх виробництва або заміни новими зразками.

\section{Аналіз останніх досліджень та публікацій}

Проблема визначення граничного стану не $\epsilon$ новою, нею займалось багато дослідників, які умовно можливо поділити на два основні напрямки: силові дослідження та статистичні. Чіткої межі між ними немає, кожні дослідження містять в собі обидва елементи в різній відносній кількості.

Основою в визначенні силових елементів $\epsilon$ застосування теорії опору матеріалів. Дослідники будують свої гіпотези навколо силової моделі напружено-деформованого стану, до якої прикладені навантаження, які отримують в експлуатаційних умовах, перераховують ресурсні показники використовуючи втомні методи та порівнюють із встановленим розробником ресурсу. Найбільш розгорнуто ці методи висвітлені в таких працях, як [3-8] та інші.

Щодо статистичних досліджень дослідники широко використовують статистичні матеріали в теорії ймовірностей, математичної статистики і теорії розпізнавання образів. Із маючого значного масиву статистичних даних, дослідники формують еталонні образи технічного стану та намагаються визначити належність досліджуваного об'єкта до певного образу. Ці методи достатньо висвітлені в таких працях, як [9-12] та інші.

\section{Постановка завдання}

Кожен з напрямів визначення граничного стану застосовується при певних обмеженнях. Основний недолік в силових дослідженнях - відсутність вхідних даних (та в деяких випадках і спеціальних методик), за якими проводились розрахунки на втому досліджуваного силового елемента, оскільки ці дані, зазвичай, є комерційною таємницею виробника. Ця проблема гостро стоїть перед Україною, оскільки парк літаків-винищувачів Повітряних Сил є іноземного виробництва, та виробник припинив супроводження цих літаків. Що стосується статистичних методів, то основною проблемою в реалізації цих методів є необхідність мати істотної кількості статистичних даних за досить тривалий термін експлуатації досліджуваного об'єкта, а також необхідність мати визначальні параметри, які вносять найбільший (або вирішальний) вклад в вичерпання ресурсу в досліджуваному об'єкті.

В даній статті викладені результати спроби автора синтезувати силові та статистичні методи оцінювання технічного стану силових елементів планера літаків-винищувачів на прикладі основного стояка шасі літаківвинищувачів авіації Повітряних Сил Збройних Сил України та приведено загальний алгоритм виконання методики.

\section{Виклад основного матеріалу}

Методика оцінювання технічного стану силових елементів літаків-винищувачів за межами призначених показників включає в себе такі часткові методики: методика обробки експлуатаційних даних польотних циклів для попереднього оцінювання можливості збільшення призначеного ресурсу силовим елементам, методика визначення напружено-деформованого стану силових елементів літаків-винищувачів за результатами польотних циклів та методика оцінювання накопиченої пошкодженості силових елементів літаків-винищувачів за даними польотних циклів. Відповідно переліченню зазначених часткових методик застосування їх йде саме в такому порядку.

Отже, на початку застосовується методика обробки експлуатаційних даних польотних циклів для попереднього оцінювання можливості збільшення призначеного 
ресурсу силовим елементам. Ця методика включає в себе 8 етапів (рис. 1):

1. На першому етапі визначається тип необхідних статистичних даних. Дані планується отримувати із бортових реєстраторів польотних параметрів у продовж циклу “земля-повітря-земля", які складають основне навантаження на силовий

1. Визначення
дипу необхідних
даних

елемент в експлуатації. Щодо стояків шасі основними типами статистичних даних обрано посадкову $\mathrm{T}_{\text {пос }}$ та злітну масу $\mathrm{T}_{\text {зліт }}$

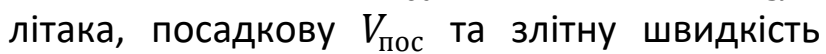

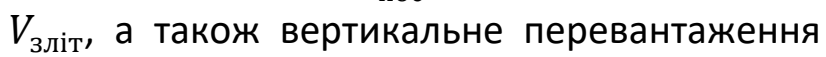
при посадці пу;

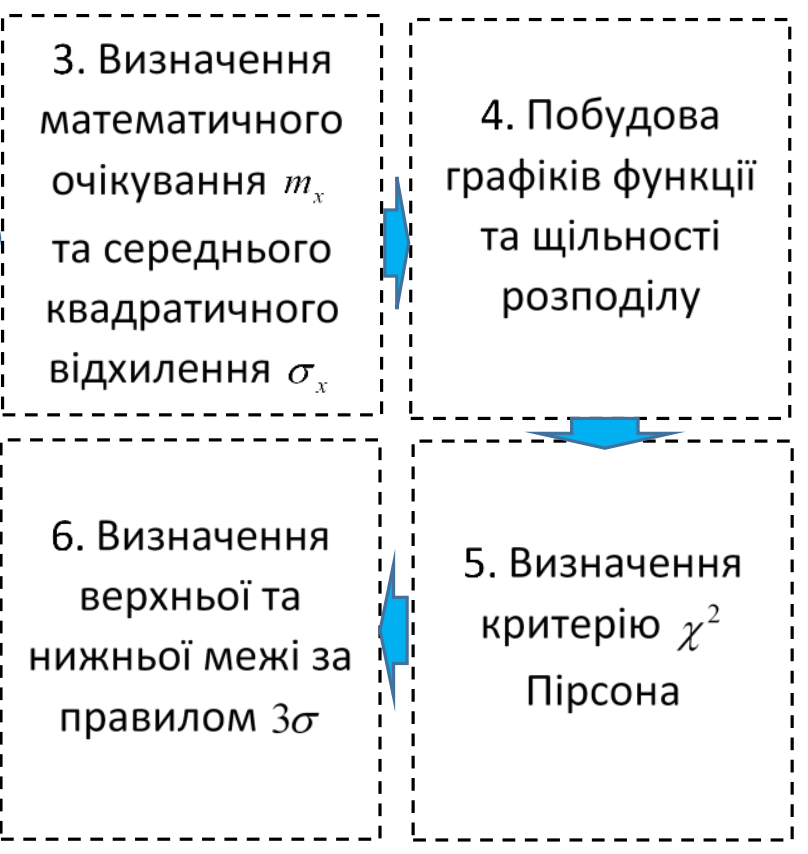

Рисунок 1 - Алгоритм виконання методики обробки експлуатаційних даних польотних циклів для попереднього оцінювання можливості збільшення призначеного ресурсу силовим елементам

2. На другому обрані дані отримуються із експлуатуючих частин та зводяться в окремі масиви даних для їх подальшої обробки;

3. Третій етап передбачає визначення основних числових характеристики обраних статистичних даних, а саме математичного очікування $m_{\mathrm{x}}$ та середнього квадратичного відхилення $\sigma_{x}$;

4. Четвертий етап передбачає побудову графіків функції та щільності розподілу статистичних даних за висунутою гіпотезою нормального закону розподілу;

5. На п'ятому етапі за допомогою критерію $\chi^{2}$ Пірсона вираховується ймовірність того, що статистичні дані приймуть саме нормальний закон розподілу із обраним рівнем значущості. У разі, якщо статистичні дані прийняли інший закон розподілу необхідно врахувати це в наступних етапах;
6. Шостий етап передбачає визначення верхньої та нижньої межі значень за допомогою правила $3 \sigma$ (у разі нормального закону розподілу) для кожної статистичного параметру;

7. На сьомому етапі визначають основні випадки навантаження силового елемента в експлуатації. Відповідно до стояків шасі - це вертикальні, лобові та бокові навантаження;

8. Восьмий етап передбачає розрахунок зазначених випадків навантаження за розрахунковими та максимальними експлуатаційними параметрами. Розрахункові значення, зазвичай, отримують iз норм міцності, а максимальні експлуатаційні - із верхньої межі статистичних даних $(+3 \sigma)$. Порівняння цих навантажень надає можливість оцінити інтенсивність експлуатації парку силових 
елементів. Якщо парк силових елементів експлуатувався із максимальними значеннями (або наближеними до них) - тоді пошук запасів ресурсу у досліджуваних елементах має високі ризики, але якщо силовий елемент експлуатувався не в повній мірі від розрахункових значень - тоді ймовірність наявності запасів невичерпаного ресурсу є значною.

Основні результати, які отримані в ході розрахунків за вище наведенню методикою зображені на рисунку 2. Більш детально ознайомитись із дослідженнями за цією методикою можливо в роботі [13].

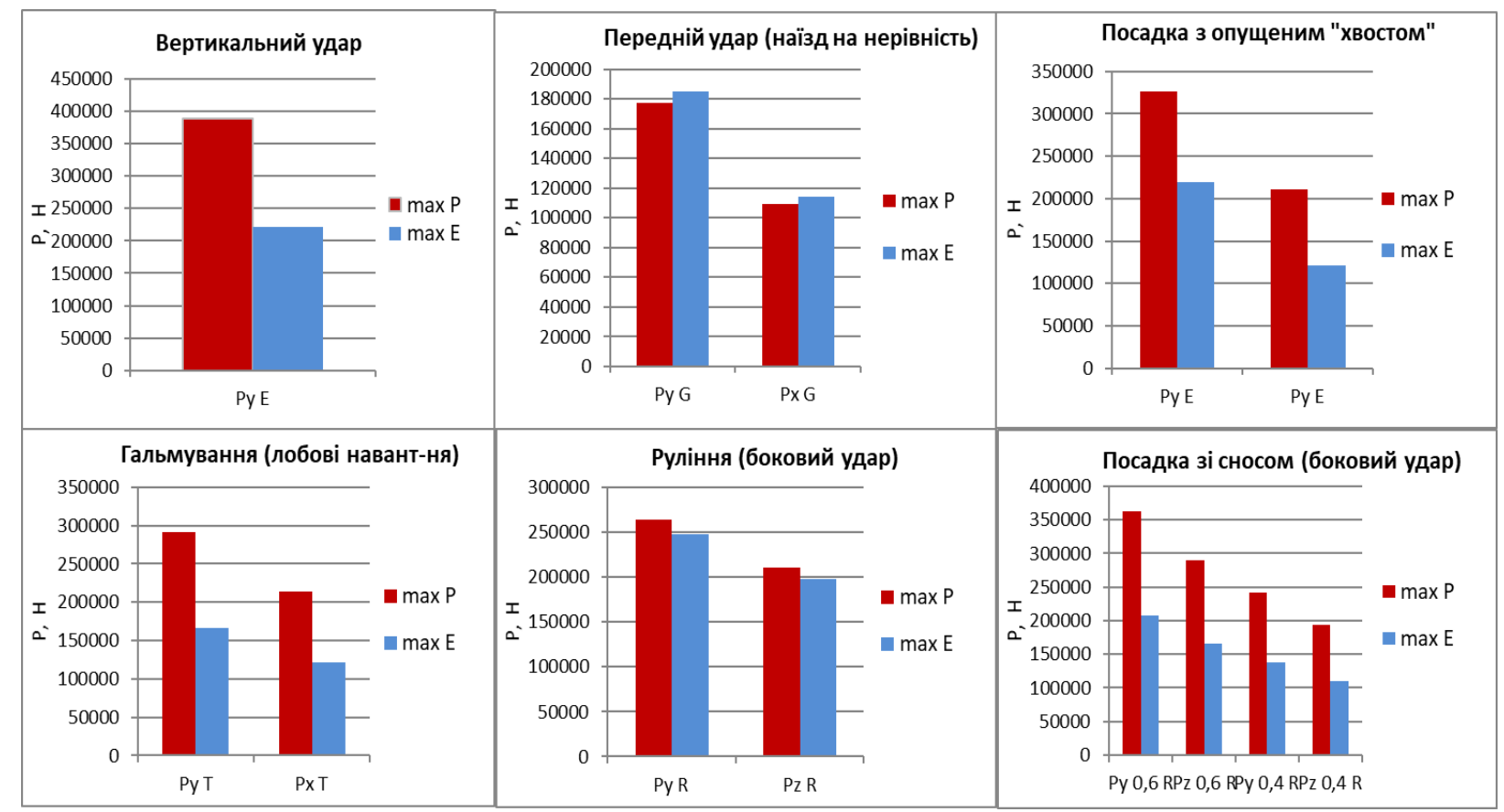

Рисунок 2 - Основні результати виконання методики обробки експлуатаційних даних польотних циклів для попереднього оцінювання можливості збільшення призначеного ресурсу силовим елементам

Наступний крок в розрахунках застосування методики визначення напружено-деформованого стану силових елементів літаків-винищувачів за результатами польотних циклів. Методика застосовує метод кінцевих елементів для вирішення задачі механіки твердого тіла. Задача цього кроку - визначити критичні точки в конструкції досліджуваного об'єкта, до яких необхідно застосовувати засоби неруйнівного контролю в процесі експлуатації за межами призначеного ресурсу. Існує досить багато програмних пакетів, які застосовують метод кінцевих елементів, проте автор використовував в своїх розрахунках програмний пакет SolidWorks. Методика включає в себе 4 основні етапи (рис. 3):
1. Формування геометричної моделі у 3-х вимірному просторі. Для формування моделі використовують креслення досліджуваного об'єкта в натурному розмірі;

2. Формування кінцево-елементарної сітки в моделі. Зазвичай, чим дрібніша сітка - тим точніший результат, проте сітка формується опираючись на можливості комп'ютера;

3. Моделювання межових умов. Межові умови, які застосовуються до досліджуваного об'єкта (на прикладі силового елемента конструкції літака), зазвичай включають в себе характеристики матеріалу, 3 якого виготовлений об'єкт дослідження, точки (або зони) кріплення та характеристики кріплення, а також зовнішні навантаження та впливи;

4. Останній етап включає рішення системи рівнянь та аналіз результатів. 


\section{Відповідно до стояка шасі літака- експлуатації. Більш детальне ознайомлення 3 винищувача - побудовано модель, розрахунками межових умов та критичних сформована кінцево-елементарна сітка та місць конструкції за класичними методами, а прикладені межові умови. Аналіз результатів також послідовність побудови моделі в 3-х (рис. 4) дозволив виявити три основні вимірному просторі можливо в роботах [14, критичні точки конструкції, які корегуються із 15].} попередніми розрахунками і досвідом

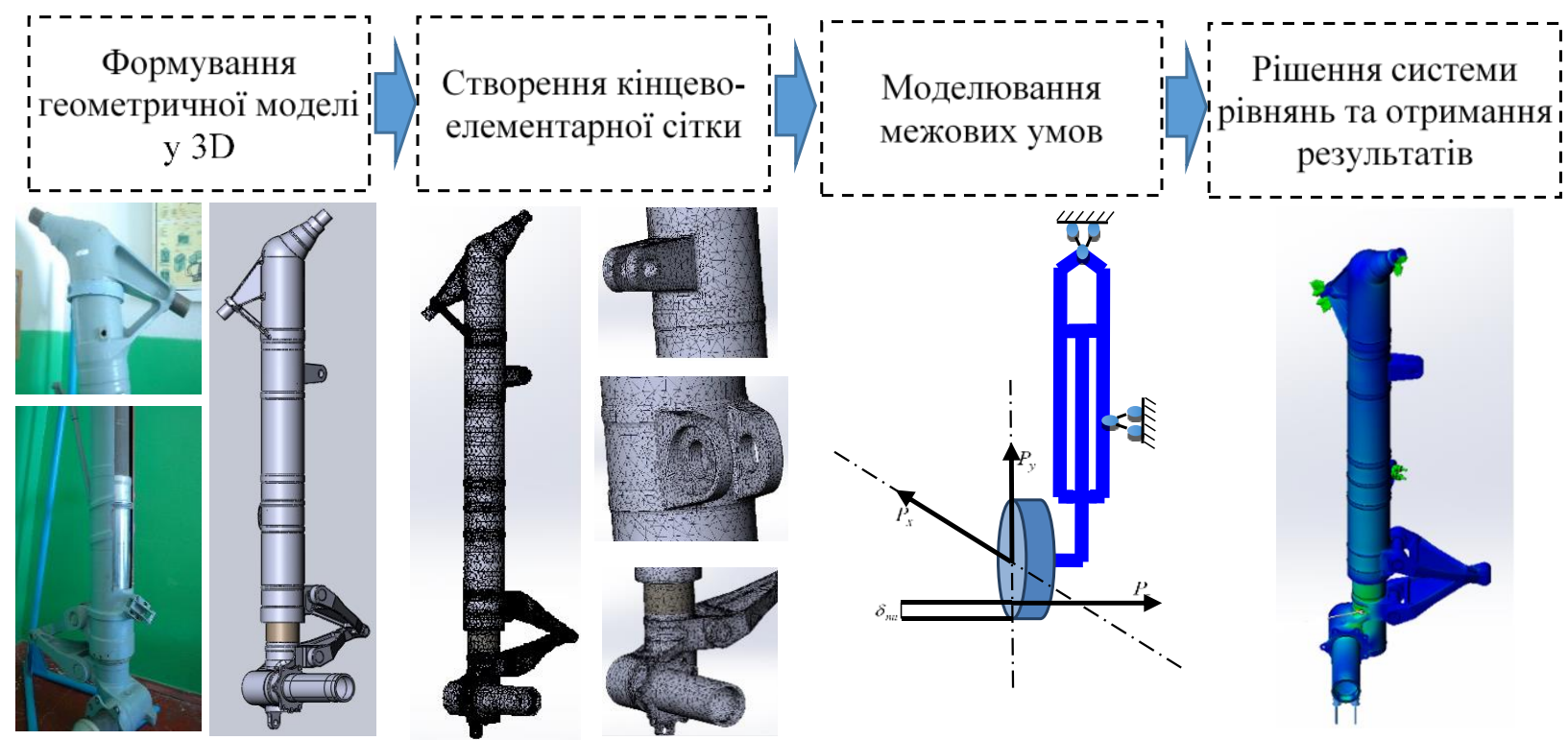

Рисунок 3 - Алгоритм виконання методики визначення напружено-деформованого стану силових елементів літаків-винищувачів за результатами польотних циклів із проміжними результатами

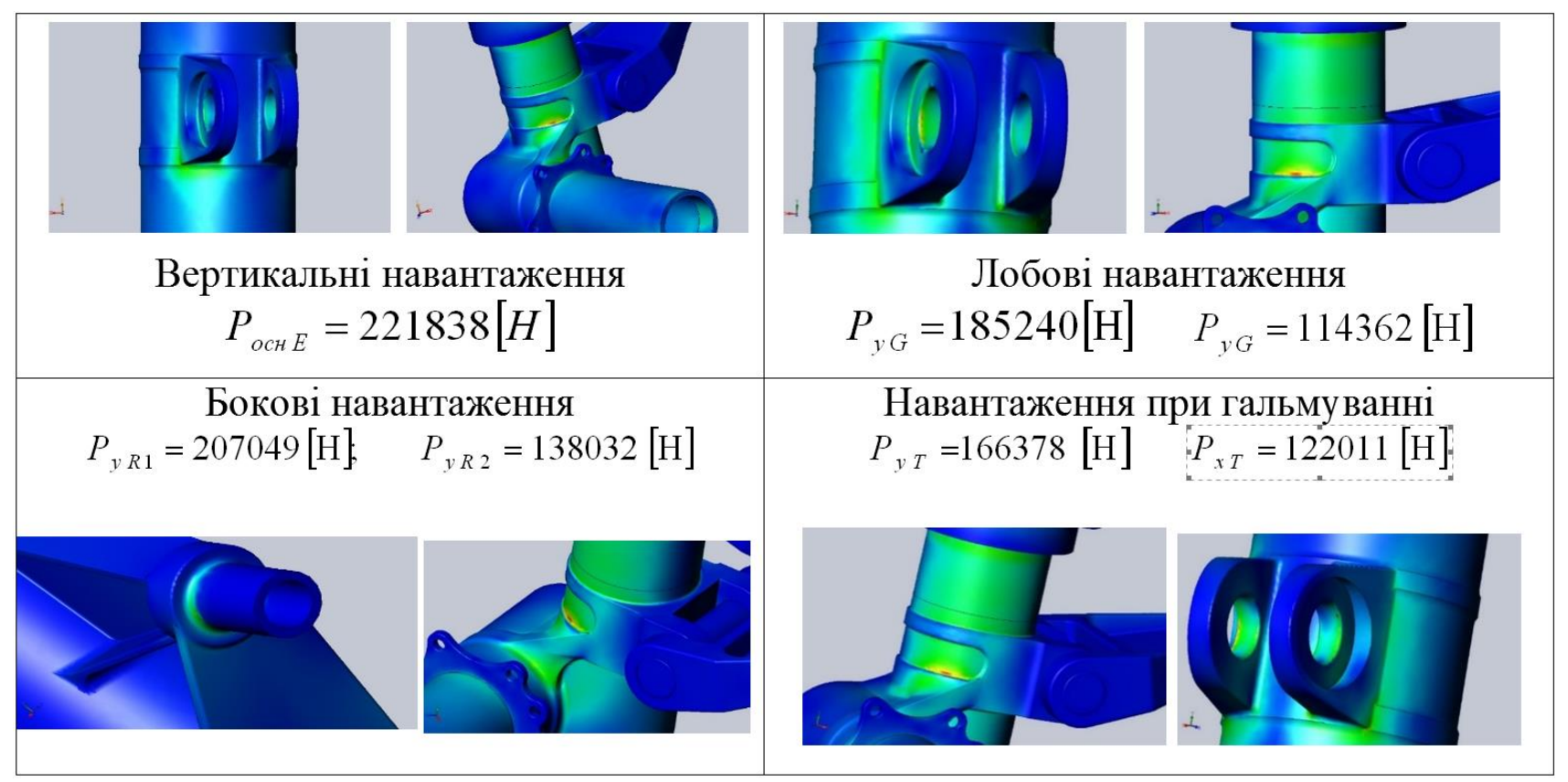

Рисунок 4 - Критичні точки конструкції стояка шасі літака-винищувача

Останній крок в оцінюванні технічного стану досліджуваного об'єкта - методика оцінювання накопиченої пошкодженості силових елементів літаків-винищувачів за даними польотних циклів. Основна задача цього кроку - оцінка накопиченої 
пошкодженості досліджуваного об'єкта та Складається ця методика з 5-х основних
остаточна класифікація технічного стану. кроків (рис. 5):

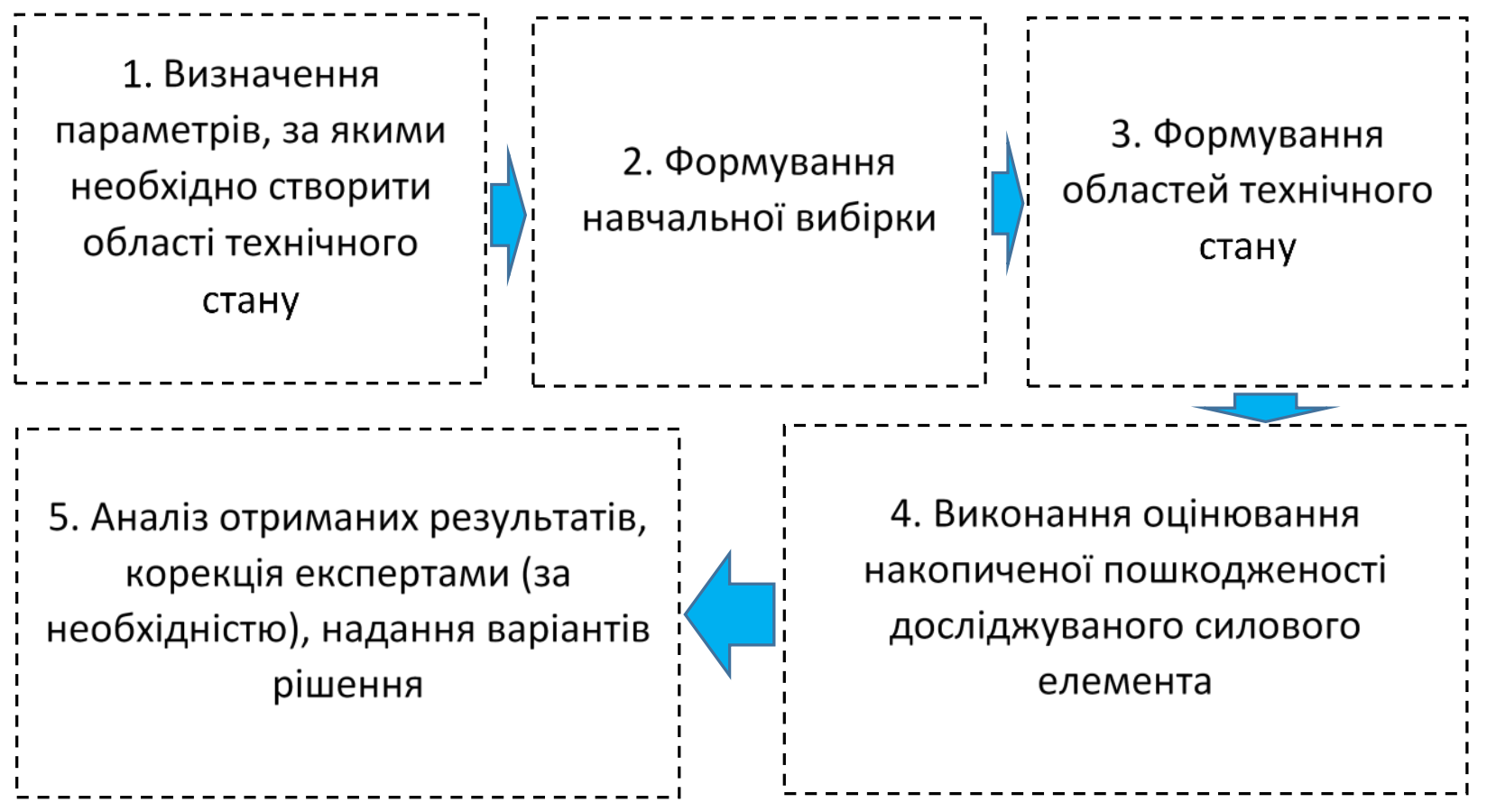

Рисунок 5 - Алгоритм виконання методики оцінювання накопиченої пошкодженості силових елементів літаків-винищувачів за даними польотних циклів

1. Визначення параметрів, за якими необхідно створити області технічного стану. Цей крок дуже важливий, оскільки параметри повинні мати визначальну значущість, тобто безпосередньо впливати на вичерпання ресурсного потенціалу;

2. Формування навчальної вибірки. Навчальна вибірка формується із як можливо більшої кількості таких самих конструктивних елементів, як і досліджуваний об'єкт. Можливо також формувати вибірку із інших конструктивних об'єктів, які також можуть надати можливість виконати оцінку технічного стану досліджуваного об'єкта. Зазвичай формується навчальна вибірка із різноманітних об'єктів, які сильно відрізняються один від одного за різними параметрами (залишок ресурсу, інтенсивність експлуатації, дані засобів неруйнівного контролю та інші.). Також формування навчальної вибірки проводиться із урахуванням необхідної кількості областей технічного стану;
3. Формування областей технічного стану. Зазвичай, формується два образи технічного стану, які протилежні один одному (наприклад: “Задовільний” та “Граничний”). Проте математична модель дозволяє формувати декілька областей, за якими необхідно оцінити технічний стан досліджуваного об'єкта. Формування областей пропонується виконувати за допомогою метода кластеризації "ForEl-1";

4. Виконання оцінювання накопиченої пошкодженості досліджуваного силового елемента. Цей етап передбачає внесення навчальної вибірки та досліджуваного об'єкта в математичну модель розпізнавання образів технічного стану. Пропонується використовувати статистичний метод розпізнавання образів;

5. Аналіз отриманих результатів, корекція експертами (за необхідністю), надання варіантів рішення.

В ході досліджень стояків шасі літаківвинищувачів визначені основні визначальні параметри, це наробіток (кількість посадок) 3 
початку експлуатації $N_{E}$, середнє стану, а саме із областями “Задовільний” та квадратичне відхилення перевантаженняпри “Граничний". Аналіз розрахунків надав посадці $n_{y}$ та математичне очікування можливість зробити висновок, що

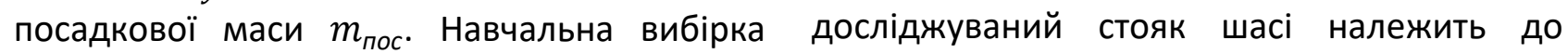
сформована із 9 стояків шасі одного типу із образу "Задовільний" із імовірністю близької досліджуваним стояком, та формування до одиниці (рис. 6). Більш детально вибірки відбувалось із урахуванням ознайомитись із даною методикою можливо необхідної кількості областей технічного в роботах [16-18].

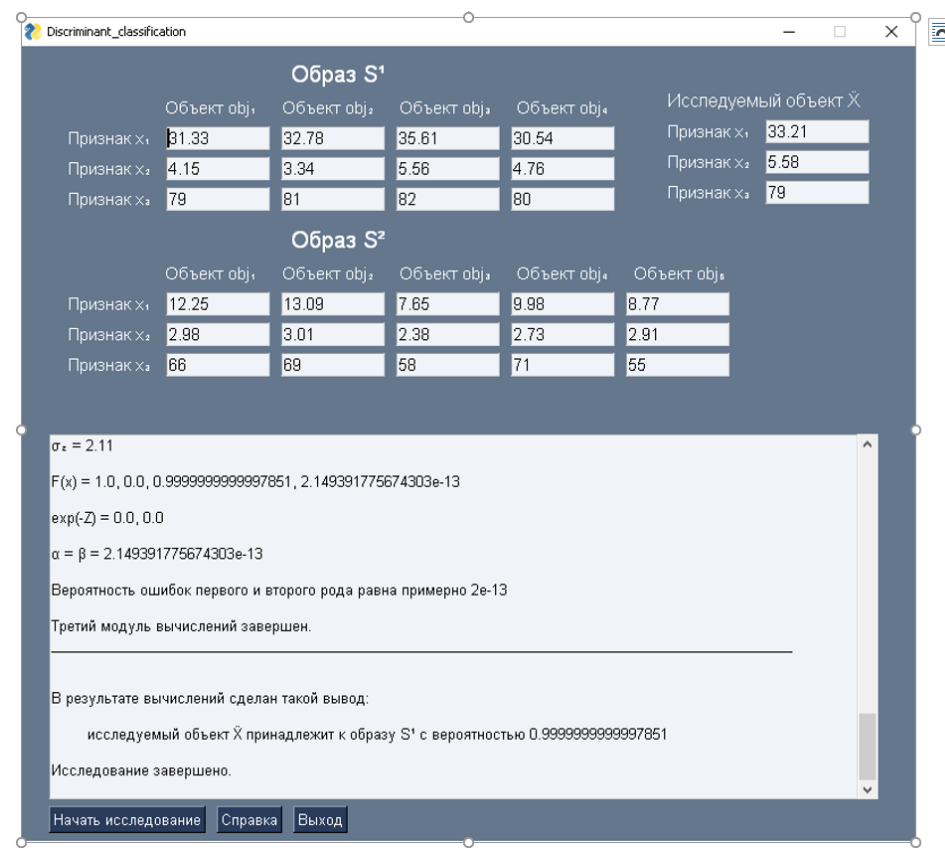

\section{Логарифм правдоподібності $\ln \widehat{L}=35,65$.}

Отже, $\ddot{X} \in S^{1}$ із ймовірністю
$P=0,999$

Рисунок 6 - Результати оцінювання пошкодженості стояка шасі літака-винищувача

Враховуючи всі вище перелічені часткові методики можливо узагальнити в одну методику, яка матиме певну послідовність кроків або дій. На рисунку 7 зображена загальна методика у вигляді логічної блоксхеми, яка втілює в собі синтез силових та статистичних методів оцінювання технічного стану силових елементів. Відповідно умовні розділи блок-схеми відповідають описаним вище частковим методикам, а саме перший розділ - першій частковій методиці, другий розділ - другій частковій методиці, третій, четвертий та п'ятий - третій частковій методиці.

При застосуванні досліджуваного стояка шасі літака-винищувача до цій методиці, результат розрахунків матиме таке управлінське рішення: “Об”єкту допускається продовжувати ресурс в межах військової частини із застосуванням методів неруйнівного контролю в критичних точках та не допускати до експлуатації пілотів 2 класу та нижче, або допустити до експлуатації без обмежень при виконанні капітального ремонту на АР3". 


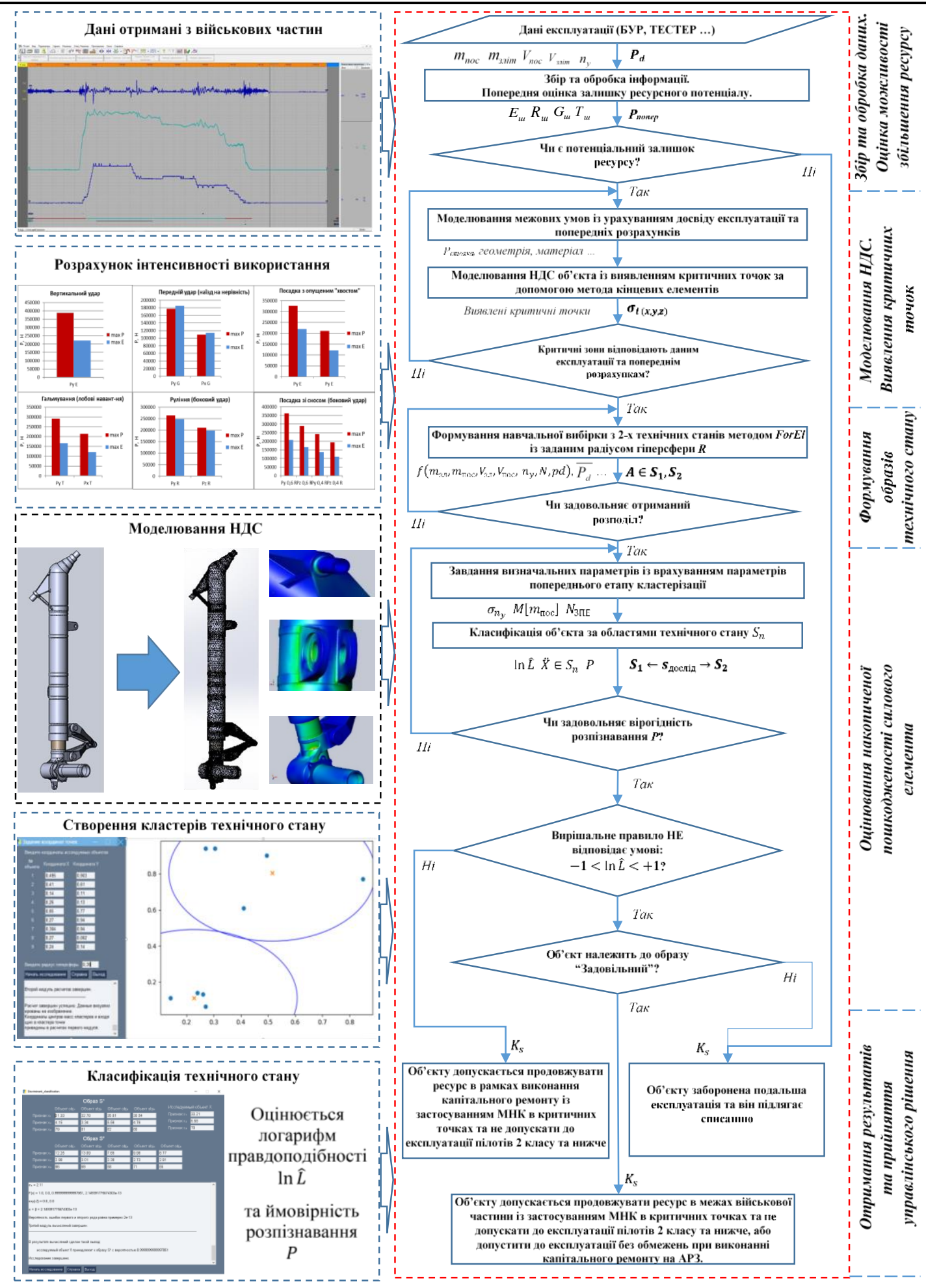

Рисунок 7 - Алгоритм виконання методики оцінювання технічного стану силових елементів літаків-винищувачів за межами призначених показників

\section{Висновки}

В статті наведено синтез силових та статистичних методів класифікації технічного стану силових елементів літальних апаратів у вигляді загальної методики, застосування якої надасть можливість більш об'єктивно приймати рішення щодо продовження призначеного ресурсу та подальшої експлуатації силового елемента у складі літака-винищувача. 


\section{Список використаних джерел}

1. Воєнна доктрина України: за станом на 2вересня 2015p./Президент України. К.: Презид. вид-во, 2015, - 27 с.

2. Візія Повітряних Сил 2035 - травень 2020, 42 с. - Міністерство оборони України.

3. Стрижиус В.Е. Методы расчета усталостной долговечности элементов авиаконструкций. М.: Машиностроение, 2012, 272 c.

4. Воробьев А.З., Олькин Б.И., Стебенев В.Н. и др. Сопротивление усталости элементов конструкций. М.: Машиностроение, 1990, $240 \mathrm{c}$.

5. Труды ЦАГИ. 1981, Вып. 2117.

6. Брондз Л.Д. Технология обеспечения ресурса самолетов. М.: Машиностроение, 1986, 184 c.

7. Серенсен С.В., Когаев В.П., Шнейдеровнич P.M. Несущая способность и расчеты деталей машин на прочность. М.: Машиностроение, 1975, 488 с.

8. Когаев В.П., Махутов Н.А., Гусенков А.П. Расчеты деталей машин и конструкций на прочность и долговечность. М.: Машиностроение, 1985, 224 с.

9. Фомин Я.А. Диагностика кризисного состояния предприятия: М.: ЮНИТИ-ДАНА, 2003, 349 c.

10. Фукунага К. Введение в статистическую теорию распознавания образов. М.: Наука, 1979.

11. Акофф Р., Сасиени М. Основы исследования операций. М.: Мир, 1971.

12. Загоруйко Н.Г. Методы распознавания и их применение. М.: Советское радио, 1972, 208 c.
13. Добриденко О.М., Ковель П.П., Стрєла М.С. Аналіз і порівняння навантажень, що діють на стояк шасі літака типу Су-27 в розрахункових та експлуатаційних умовах // Збірник наукових праць ДНДІА, Nо. вип. 13(20), 2017. С. 135.

14. Бойко А.П., Манулін Ю.О., Стрєла М.С. Аналіз напружено-деформованого стану основного стояка шасі літаків типу Су-27 при визначенні можливості його подальшої експлуатації за межами призначених показників // збірник наукових праць ДНДІА, № вип. №12(19), 2016. С. 245.

15. Добриденко О.М., Стрєла М.С. Побудова моделі та розрахунок на міцність стулки повітрозабірника літака типу МиГ-29 // Збірник наукових праць ДНДІА, № вип. 14(21), 2018. С. 168.

16. Добриденко О.М., Стрєла М.С. Розроблення методики кластеризації технічного стану силових елементів літаків-винищувачів // Труди Університету, 2020.

17. Strela, M., Dobridenko, O., \& Gorokhov, G. (2020). Evaluation (classification) of power elements by areas of technical condition using the statistical recognition method and the expert method. Journal of Scientific Papers "Social Development and Security", 10(4), 3-11. DOI: 10.33445/sds.2020.10.4.1

18 Bolohin, A., Strela, M. (2021). Estimation of aircraft power elements by areas of technical condition using clustering algorithm and statistical recognition method. Political Science and Security Studies Journal, 2(1), 7483. DOI: $10.5281 /$ zenodo.4924240

\section{Методика оценки технического состояния силовых}

\section{элементов самолетов-истребителей за пределами назначенных показателей}




\begin{abstract}
Аннотация
Согласно Визии Воздушных Сил планируется обновление парка летательных аппаратов на новые самолеты, находящихся на вооружении стран НАТО. Однако, в переходный период переоснащение на новую технику возникает проблема поддержания исправности стареющего парка самолетов. Основная проблема в обеспечении исправности парка самолетов Воздушных Сил - это значительное исчерпание ресурсных показателей из-за высокой интенсивности полетов. Цель статьи состоит в обнародовании результатов исследований по комплексу частных методик оценки технического состояния силовых элементов самолетов-истребителей, когда их формальный ресурс исчерпан. Эти частичные методики составляют общую методику оценки технического состояния силовых элементов самолетов-истребителей за пределами назначенных показателей. Использование общей методики позволит более объективно принимать решение о продлении (увеличении) ресурса силовым элементам самолетов-истребителей и определять их техническое состояние с большей точностью. Общая методика использует в расчетах теорию вероятностей при обработке эксплуатационных данных, теорию механики твердого тела и метод конечных элементов при расчете напряженнодеформированного состояния, метод кластеризации и теорию распознавания образов при классификации технического состояния. Несмотря на использование такого многообразия различных видов математических расчетов - методика интуитивно понятна и достаточно практична.
\end{abstract}

Ключевые слова: летательный аппарат, силовой элемент, ресурс, оценка технического состояния.

\title{
Methods for assessing the technical condition of the power elements of fighter aircraft outside the assigned indicators
}

\author{
Maxim Strela * 1 A \\ Corresponding author: *1 Researcher of the Research Laboratory, e-mail: maxim.strela1991@gmail.com, ORCID: 0000-0003-4055-1600 \\ A State Aviation Research Institute, Kyiv, Ukraine
}

\begin{abstract}
According to the Vision of the Air Force, it is planned to upgrade the fleet of aircraft to new aircraft in the service of NATO countries. However, in the transition period of re-equipment with new equipment there is a problem of maintaining the serviceability of the aging fleet. The main problem in ensuring the serviceability of the Air Force aircraft fleet is a significant depletion of resource indicators due to the high intensity of flights. The purpose of the article is to publish the results of research on a set of partial methods for assessing the technical condition of the power elements of fighter jets, when their formal resource is exhausted. These partial methods are a general method of assessing the technical condition of the power elements of fighter aircraft outside the assigned indicators. The use of the general technique will allow to make more objective decisions on the continuation (increase) of the resource of the power elements of fighter aircraft and to determine their technical condition with greater accuracy. The general technique uses in the calculations the theory of probabilities in the processing of operational data, the theory of solid mechanics and the finite element method in the calculation of the stress-strain state, the method of clustering and the theory of pattern recognition in the classification of technical condition. Despite the use of such a variety of different types of mathematical calculations - the method is intuitive and quite practical.
\end{abstract}

Keywords: aircraft, power element, resource, technical condition assessment. 


\section{References}

1. Military doctrine of Ukraine: behind the camp on the 2nd of Spring 2015 / President of Ukraine. Kyiv: President. view, 2015, 27 p.

2. Visit of the Powers 2035 - May 2020, 42 p. Ministry of Defense of Ukraine.

3. Strizhius V. E. Methods for calculating the fatigue life of aircraft structural elements. Moscow: Mashinostroenie, 2012, 272 p.

4. Vorobiev A.Z., Olkin B.I., Stebenev V.N. and other Resistance to fatigue of structural elements. Moscow: Mashinostroenie, 1990, $240 \mathrm{p}$.

5. Proceedings of TSAGI. 1981, no. 2117.

6. Bronds L. D. Aircraft resource provision technology. Moscow: Mashinostroenie, 1986, 184 p.

7. Serensen S.V., Kogaev V.P., Shneiderovich R.M. Bearing capacity and strength calculations of machine parts. Moscow: Mashinostroenie, 1975, 488 p.

8. Kogaev V.P., Makhutov N.A., Gusenkov A.P. Calculations of machine parts and structures for strength and durability. Moscow: Mashinostroenie, 1985, 224 p.

9. Fomin Ya.A. Diagnostics of the crisis state of the enterprise: Moscow: UNITI-DANA, 2003, $349 \mathrm{p}$.

10. Fukunaga K. Introduction to the statistical theory of pattern recognition. Moscow: Nauka, 1979.

11. Ackoff R., Sasieni M. Basics of Operations Research. Moscow: Mir, 1971.

12. Zagoruiko N.G. (1972) Recognition methods and their application. Moscow: Soviet radio, $208 \mathrm{p}$.
13. Dobridenko O.M., Kovel P.P., Strela M.S. (2017) Analyze and time-to-date, how to go to the riser of the Litaka type Su-27 in rotor and operational heads. Collection of scientific works DNDIA, No. vip. 13 (20), 135.

14. Boyko A.P., Manulin Yu.O., Strela M.S. (2016) Analysis of the stressed-deformed mill of the main standpipe of the lithium type Su-27 with the designation of the possibility of the most significant operation beyond the boundaries of the indicators. Collection of Science Practices DNDIA, No. vip. No. 12 (19), 245.

15. Dobridenko O. M., Strela M. S. (2018) Pobudova model and design for the performance of a chair of a litak type MiG-29. Collection of scientific works DNDIA, no. Vip. 14 (21), 168.

16. Dobridenko O. M., Strela M. S. The breakdown of the clustering technique of technical camp of power elements from lithuanians-vinischuvachiv // Proceedings of the University, 2020.

17. Strela, M., Dobridenko, O., \& Gorokhov, G. (2020). Evaluation (classification) of power elements by areas of technical condition using the statistical recognition method and the expert method. Journal of Scientific Papers "Social Development and Security", 10(4), 3-11. DOI: 10.33445/sds.2020.10.4.1

18 Bolohin, A., Strela, M. (2021). Estimation of aircraft power elements by areas of technical condition using clustering algorithm and statistical recognition method. Political Science and Security Studies Journal, 2(1), 7483. DOI: $10.5281 /$ zenodo. 4924240 